GAIL SCOTT published Spare Parts in 1982. Her novel Heroine will appear shortly. She was a founding editor of the French-language literary magazine Spirale and is a founding editor of Tessera. Her short stories and texts have appeared in Frenchlanguage literary magazines in Québec and Paris, as well as in English-Canada.

\title{
Spaces Like Stairs
}

\author{
GAIL SCOTT
}

what's real?

the problem is in the space

example rape is a black card deck chance bad luck

as normal product of patriarchal logic

what's real

when the jolly female child is here and the syntax (bound

pornographic image) in the space

pornographic image) over there?

the problem is in the space

after ten years of textual trying ${ }^{1}$ are we ready to say how to say

what (our) real is?

she's repeating herself, the first time

the problem is in the space presently the problem is:

from what space can we best define our new culture is it in the space beyond the text ${ }^{1}$ Nicole's utopia or in order to be "clear" must we step back to older forms?

the problem is in the space the problem is in the space between ideology and consciousness (old systems new awareness in this space was born the sentence) the problem is in the space between the conscious and the unconscious (once thought poetry's pure source) out of these two spaces in fusion has come the text but what in

1. As the debate on writing in the feminine began in Québec in the mid 70s, the text, often combining fiction / theory, prose 'poetry became a privileged form for feminist writers 
rising above the others has the text left? has the text left behind sense? has the text left behind innocence (words unbridled by self-censorship what ideas are 'in' now asks the text?) no, halt this way of thinking what ideas can be more relevant for me than those created as a result of words circulating among (mostly) women? can one censor what makes one live? yet yet

perhaps the question is how to keep the new space open where women's culture rests (than thin layer) by what forms might we make it resistant to the 80 s avalanche of cooption yes how to state the facts when we are fiction to be imaginative when our fiction is biography when in order not to sink in sadness our fiction must be theory

you're representing yourself, says a voice just as we're about to ask what space might our discursive writing occupy, a voice says you're repeating yourselves but but can standards for a new culture be created if we say things only once what is beauty for us excellence may we mention only once (in the shadow of the phallus) how the sustained pleasure of two lips leads to other than dramatic climax you're repeating yourselves, says the voice your illusions are dépassé it's the $80 \mathrm{~s}$

maybe the problem is in the space between male and female reading we hear the masculine other with anxious ears what's dangerous is he doesn't hear us la femme tend toujours vers dit Irigaray. ${ }^{2}$ sans retour à elle comme lieu d'élaboration positive

2.Luce Irigaray, Ethique de la différence sexuelle, (Paris: Editions de Minuit), p. 16

Woman always tends towards the other, without returning to herself as a place of positive elaboration (transl. g.s.) 
prologue (working material)

IT happened one night. what happened? more important how to write it? the movie starred Claudette Colbert and Rock Hudson. in the black arch of starry sky the moon shone. or, in the morning mist two lovers kissed and, and... IT transpired. but what was IT? naturally she the audience saw IT other than he the audience did he's one, on the inside looking in. she's herself and Claudette at the same time. as Rock takes her in his arms the freckled hands of several men float by. Daddy's too. shhh. that was nothing. what were we doing? I don't know Mommy because I don't know what you call it. fun in the tub? seeing stars in the back yard? I wanted Mommy to change my bed but he came. Daddy daddy cries the little girl in the new coat jumping up and down beside the the smiling man while a camera draws the line between acceptable (what you see) and unacceptable seduction.

(the young Freud said: incest creates hysteria in women but he had so many patients with that ailment he got embarassed and had to change his theory. still, the question rests: for the little girl as for every woman where's the language line to separate real caring from exploitative seduction?)

she's repeating herself, the second time

the problem is in the space women sitting at a table drinking wine from bottles with painted flowers on them saying we must examine the theoretical gains of the decade we must write about our thin layer of culture in order to move it forward the essay is the form the essay is the way to write our new awareness into transformed ideology laying out the argument from start to finish but one says: I can't think in a straight line another: in fiction my imagination lacks; in theory my autobiographical notes destroy the facts

the problem is in the space if the mind works best without those distinctions between reality/theory/fiction, then the space has slipped from which the essay can spring you're repeating yourself says the voice the essay needs logic to be clear to avoid barbarism certain forms must be borrowed from the dominating culture at any rate there's no danger of self-betrayal for you women are excellent at translation women are skilled at stepping into spaces (forms) created by the patriarchal superego and cleverly subverting them true but above the reality line (as men define it) the 
female body is left behind two men meet in a university department they shake hands the shoulders swagger mr. s. I presume? how goes the thesis? the other plants his feet more firmly on the ground the beard waggles it's a phenomenal labour but you know I already have a publisher next year I'm getting tenure

the problem is in the space between our being and their saying "la source du tragique consiste non dans l'acte, mais dans la rencontre (d'abord manquée, puis graduellement réalisée) entre l'acte et le language" 3 by his own words Oedipus condemned himself and went down in history for soaring tragedy confirms existence but what if the body (act) is condemned by the language of the other (example bleeding on a white dress is disgustingly inappropriate) for as women the space between the act and the other's language has been so great we never seemed to close it daddy saying do as I say not as I do when mother wanted neither of the two

epilogue (reworked material)

the problem is in the space she's repeating herself again the problem is in the space between herself and image she used to watch herself in the surrounding world of mirrors which one was she hamlet had his words but ophelia slipped silent down the river watching the mirrors she wondered which one named her new woman amazon abandoned lover mother daddy's girl french english every image had a different way of talking every image had a different way of walking she got so dizzy she had to stop looking

yes that's the answer stop looking out at them the space beyond the text is the new place one learns best the lessons of the other culture when not bedazzled by the phallic symbol as in gertrude djuna nicole mary maybe lesbian is easier yes the old forms essay novel have moved forward maybe two post-moderns one for women one for men ours circular she's repeating herself again the problem is in the space she's glad

3. Shoshana Felman, Le Scandale du corps parlant (Paris: Editions du Seuil), p. 130.

The source of the tragic is not in the act but in the meeting (at first failed than gradually accomplished) between the act and language. (transl. g.s.) 